\title{
Determinants of Students' Entrepreneurial Intention: A Perspective of Tertiary Education in Indonesia
}

\author{
Corry Yohana ${ }^{1}$ \\ ${ }^{1}$ Faculty of Economics, Universitas Negeri Jakarta, Indonesia
}

\section{Article Info}

Article history:

Received: 07 December 2020;

Accepted: 21 March 2021;

Published: 22 March 2021.

Keywords:

Entrepreneurial Intentions; Entrepreneurship Education;

Locus of Control; Subjective Norms; Tertiary Education.

\begin{abstract}
Entrepreneurial intention measurements are important that should be managed and which can be used to enhance number of entrepreneurs from higher school graduates. This study aims to examine determinant factors affecting students' entrepreneurial intention from subjective norms, attitudes, self-efficacy, locus of control perspectives and understanding the role of entrepreneurship education. This study adopted a survey with correlation approach to obtain a greater understanding for the phenomenon. The data were collected using purposive method from questionnaire with a five-point Likert scale to voluntary respondents and were analyzed using SPPS application. The findings of the study indicate that the variable of subjective norm, attitude, self-efficacy, locus of control, entrepreneurship education and adversity quotient successfully drive students' entrepreneurial intention. This study suggests to pay attention these variables in driving students' entrepreneurial intentions.
\end{abstract}

\section{How to Cite:}

Yohana, C. (2021). Determinants of Students' Entrepreneurial Intention: A Perspective of Tertiary Education in Indonesia. Jurnal Pendidikan Ekonomi \& Bisnis, 9(1), 54-63. https://doi.org/10.21009/JPEB.009.1.6 


\section{INTRODUCTION}

The success of nations' development is determined by entrepreneurship (Oluyemi et al., 2018). The underlying rationale is that entrepreneurship can promote greater job opportunities and poverty alleviation expected to increase community welfare (Shepherd et al., 2020; Lin et al., 2020). Some scholars also demonstrated the influence of entrepreneurship and economic growth (Ferreira et al., 2017; Bosma et al., 2018; Urbano et al., 2019). Since the important role of entrepreneurship, enhancing the number of entrepreneurs being a crucial issue. However, the data from Statistics Indonesia (2019) documented that university graduates still provide a high portion of unemployment in Indonesia. Similarly, Saptono et al. (2020) remarked that unemployment is from elementary, junior high, high school graduates, and tertiary education.

Dealing with this matter, the government has provided campaigns to promote entrepreneurs' birth through various program both in formal and informal settings (Wardana et al., 2020). In formal education, the government focuses on the implementation of entrepreneurship education that is being entrepreneurs (Papagiannis, 2018). Badri and Hachicha (2019) remarked that entrepreneurial intention is of someone's action and willingness to start their own business. Through entrepreneurship education, it is forecasted can change the students' mindset of being entrepreneurs (Cui et al., 2019). In fact, students are afraid to take risks and tend to choose to be private employees, civil servants as their career (Wardana et al., 2020). This condition shows that the intention of being an entrepreneur is at a low level. The lack of entrepreneurial intentions among college graduates needs to be a concern. Higher education needs to encourage students to be brave in entrepreneurship as a career choice (Tognazzo et al., 2019).

In addition to entrepreneurship education, several factors can influence students' entrepreneurial intention. The first factor comes from internal, which is subjective norms (Santos \& Liguori, 2019). Subjective norm is the opinion, hope, or desire of the closest or most important person to an individual who can influence that individual's behavior (Fenech et al., 2019). The initial survey in Jakarta showed that students took most actions by asking their parents and friends for their opinions (Wibowo et al., 2018). Therefore, their decision to take action is related to the important person's opinion (Fethi \& Mohammed, 2019). Indeed, Yousaf et al. (2015) remarked that subjective norms have an important role in developing students' intentions to become entrepreneurs.

Students' attitude also has an acquaintance with the intention of being entrepreneurs. Attitude is the tendency to learn to respond consistently good or unfavorably concerning several objects (Ajzen, 2005). Entrepreneurship intends to be positive if individuals consider that entrepreneurship is the right choice to do and vice versa. Similarly, Putra et al. (2015) pointed out that student intentions tend to be positive if their attitude is also positive. This tendency will significantly determine students to start a business or become entrepreneurs (Linan \& Chen, 2009; Yohana et al., 2020). In addition to attitude, self-efficacy plays a significant role in determining individual intentions. Hsu et al. (2019) defined self-efficacy as a self-perception of how well you can function in certain situations (Sahin et al., 2019). Self-efficacy is related to the belief that one has the ability to take the expected action. Some prior studies believe that the level of self-efficacy can affect students' entrepreneurial intentions (Yohana et al., 2016).

The next factor that affects entrepreneurial intentions is the locus of control. Locus of control is a personality variable that can be defined as an individual's belief in his or her ability to control one's own fate (Mat et al., 2015). Enterprising people believe that their personality makes things happen in certain situations and underestimate the importance of fate (Asante \& Affum-Osei, 2019). Previous research conducted by Adnyana and Purnami (2016) noted that the locus of control greatly influences students' intention to start a business. Furthermore, the adversity quotient is a variable that determines whether a person continues to hope and continues to be in control in difficult situations. The adversity quotient is a measure of your response to adversity. Handaru et al. (2015) confirmed that individuals who have the intelligence to face obstacles will have the ability to seize business opportunities because they have the ability to take risks, are oriented towards opportunities or initiatives, have creativity, independence, and the ability to mobilize resources. 
Individuals who have an adversity quotient will be able to move existing obstacles or challenges into opportunities with various creativity and abilities possessed by individuals.

Since the crucial role of entrepreneurship, it has raised attention among scholars. For instance, Wedayanti and Giantari (2016) found a positive and significant influence on subjective norms and entrepreneurial intentions. Putra et al. (2015) noted that Entrepreneurial attitudes affect students' entrepreneurial intentions. Besides, Handaru (2015) revealed that the level of selfefficacy can affect students' entrepreneurial intentions. In addition, Yohana et al. (2016); Karyaningsih and Wibowo (2017) remarked that locus of control has a big influence on student intention to start a business. However, scholars' attention is the perspective of tertiary education and involving subjective norms, attitudes, self-efficacy, locus of control, and entrepreneurship education altogether. Therefore, this study aims to fill the existing gaps and contribute to the literature from tertiary education perspectives. This study also adds insight from students' internal aspects that can offer to policymakers and universities in creating a model of entrepreneurship education.

\section{METHOD}

This research was conducted at the Faculty of Economics, Universitas Negeri Jakarta in Indonesia. As for a reason for researching, this college concerned with entrepreneurship both in practice and theory. This research adopted a quantitative method of a correlational approach. This survey involved primary data from an online questionnaire to the voluntary respondents. The respondent of this research was approximately 180 tertiary students who take entrepreneurship courses and the researchers using a purposive sampling method. The process of developing the instrument begins with the preparation of an instrument in the form of a Likert scale questionnaire 1-5, where one means strongly disagree, and five means strongly agree, referring to the model indicators of subjective norm variables, attitudes, self-efficacy, locus of control, entrepreneurship education and difficulties, adversity quotient and entrepreneurial intentions. Furthermore, the data were processed using the SPSS application program. There are several steps in analyzing the data in this study: validity testing, reliability testing, normality testing, and multiple regression analysis, t-test and the coefficient of determination (R2). The detail of the design of the study is illustrated in Figure 1.

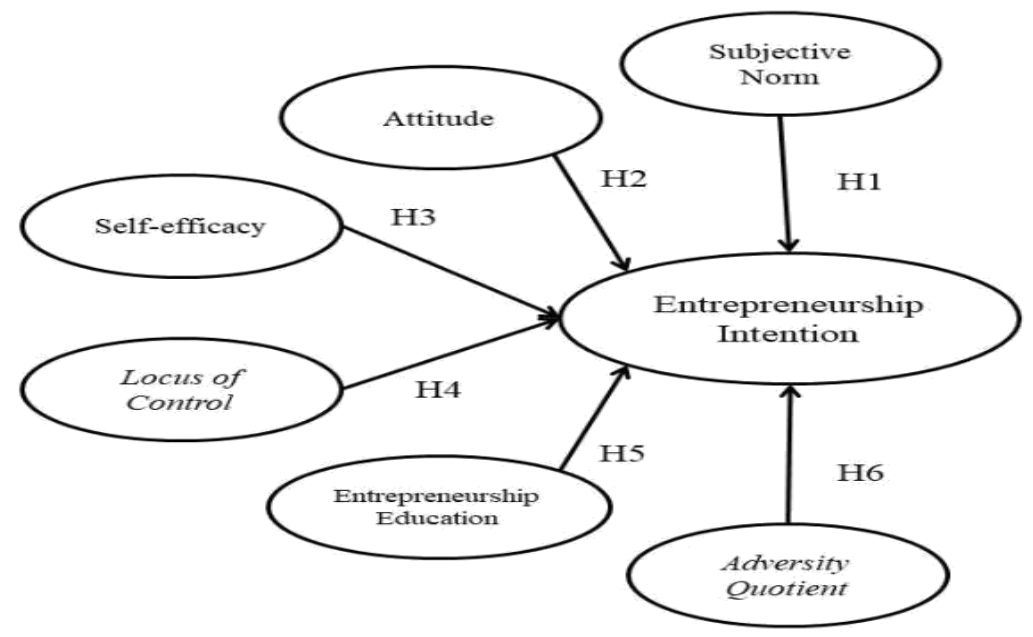

Figure 1. The theoretical framework

Hypothesis:

$\mathbf{H}_{1}$ : Subjective norm affects students' entrepreneurial intentions

$\mathbf{H}_{2}$ : Attitude affects students' entrepreneurial intentions

$\mathbf{H}_{3}$ : Self-efficacy affects students' entrepreneurial intentions

$\mathbf{H}_{4}$ : Locus of control affects students' entrepreneurial intentions 
H5: Entrepreneurship education influences students' entrepreneurial intentions

$\mathbf{H}_{6}$ : Adversity quotient influences students' entrepreneurial intentions

\section{RESULTS AND DISCUSSION}

Table 1 illustrates the demographic respondent engaged in this study. In general, the respondents come from various subject studied, with Management subject as the highest percentage (21.11\%), while the Accounting and Secretary provided the same portion (10\%). From the table, it can be known that the participants of this were slightly dominated by female students (51.67\%). Lastly, students involved in this study come from various places in West Java of Indonesia.

Table 1. The demographic data for participants

\begin{tabular}{clcc}
\hline No & \multicolumn{1}{c}{ Characteristic } & Total & Percentage \\
\hline 1 & Gender & & \\
& Female & 93 & 51.67 \\
& Male & 87 & 48.33 \\
& Subject & & \\
& S1 Accounting & 18 & 10.00 \\
& D3 Accounting & 22 & 12.11 \\
& S1 Management & 38 & 21.11 \\
& D3 Marketing Management & 24 & 13.33 \\
& S1 Economic Education & 33 & 18.33 \\
& S1 Business Education & 29 & 16.11 \\
& D3 Secretary & 18 & 10.00 \\
& Students' domicile & & \\
& Jakarta & 13 & 7.22 \\
& Bogor & 37 & 20.56 \\
& Depok & 62 & 34.45 \\
& Tangerang & 45 & 25.00 \\
& Bekasi & 23 & 12.77 \\
\hline
\end{tabular}

\section{Validity and Reliability}

The preliminary calculation showed that all statement items constructed in the instrument are normal, which presented by the Rxy score is greater than 0.361 (Bahri \& Zamzam, 2014). This study adopted Hair et al. (2006) to determine the reliability by looking at a construct Cronbach alpha score of 0.7 and greater. The calculation results of all variables have the value of Cronbach alpha that is higher than 0.7, meaning that it has met the reliability criteria. Furthermore, it can be concluded that the intention to entrepreneurship (0.264 to 0.872 ), subjective norm (0.335 to 0.763 ), attitude (0.234 to 0.765), self-efficacy (0.306 to 0.686), locus of control (0.194 to 0.646), entrepreneurship education (0.202 to 0.891$)$ and the adversity of quotient (0.390 to 0.780). Considered valid and reliable with Cronbach Alpha (a) 0.830, 0.738, 0.835, 0.868, 0.711 and 0.698, respectively. It can be inferred that belongs to the fourth variable reliability is robust.

\section{Normality Test}

The results of the normality test show that the Kolmogorov-Smirnov value was 0.359 , and the Asymp. Sig. (2-tailed) of 0.934. These results indicate that the regression equation model is normally distributed because of Asymp. Sig. (2-tailed) 0.934 is greater than the alpha value of 0.05. 
Table 2. One-Sample Kolmogorov-Smirnov Test

\begin{tabular}{llcc}
\hline & & $\begin{array}{c}\text { Residual } \\
\text { unstandardized }\end{array}$ & $\begin{array}{c}\text { Standardized } \\
\text { Residual }\end{array}$ \\
\hline $\mathrm{N}$ & Mean & 180 & 180 \\
normal Parameters & Std. deviation & .0000000 & .0000000 \\
& Absolute & 3.08883754 & .98309737 \\
Most Extreme Differences & .040 & .040 \\
& Positive & .039 & .039 \\
& Negative & -.040 & -.040 \\
Kolmogorov-Smirnov Z & & .539 & .539 \\
Asymp. Sig. (2-tailed) & & .934 & .934 \\
\hline
\end{tabular}

a. Test distribution is Normal

The next step Analyzed multiple regression (See Table 3). The analysis resulted a regression formula, that is $\hat{\mathrm{Y}}=4.357+0.468 \mathrm{X}_{1}+0.169 \mathrm{X}_{2}+0.133 \mathrm{X}_{3}+0.353 \mathrm{X}_{4}+0.160 \mathrm{X}_{5}+0.272 \mathrm{X}_{6}$

Table 3. Results of Multiple Regression Analysis

\begin{tabular}{|c|c|c|c|c|c|c|}
\hline \multirow[b]{2}{*}{1} & \multirow[b]{2}{*}{ Model } & \multicolumn{2}{|c|}{$\begin{array}{c}\text { Unstandardized } \\
\text { Coefficient }\end{array}$} & \multirow{2}{*}{$\begin{array}{c}\text { Standardized } \\
\text { Coefficient }\end{array}$} & \multirow[b]{2}{*}{$\mathbf{t}$} & \multirow[b]{2}{*}{ Sig. } \\
\hline & & B & Std. Error & & & \\
\hline & (Constant) & 4.357 & 1775 & & 2.454 & .000 \\
\hline & Subjective norms & .468 & .125 & .303 & 3.748 & .000 \\
\hline & Attitude & .169 & .082 & .198 & 2.068 & .000 \\
\hline & Self-efficacy & .133 & .086 & .146 & 2.957 & .000 \\
\hline & Locus of Control & .353 & .117 & .296 & 3.001 & .000 \\
\hline & Entrepreneurship & & & & & \\
\hline & Education & .160 & .092 & .146 & 1.983 & .000 \\
\hline & Adverse Quotient & .272 & .076 & .059 & 4.956 & .000 \\
\hline
\end{tabular}

a. Dependent Variable: Intention Entrepreneurship

\section{Hypotheses Testing}

Testing hypotheses using the partially t-test and the coefficient of determination with the output showed on Table 4.

Table 4. Output t-Test

\begin{tabular}{lccc}
\hline \multicolumn{1}{c}{ Variables } & T & T-table & Decision \\
\hline Subjective norms (SN) & 3.748 & 1.97 & accepted \\
Attitude (ATT) & 2.068 & 1.97 & accepted \\
Self-efficacy (SE) & 2.957 & 1.97 & accepted \\
Locus of Control (LOC) & 3.001 & 1.97 & accepted \\
Entrepreneurship Education (EE) & 1.983 & 1.97 & accepted \\
Adversity Quotient (AQ) & 4.956 & 1.97 & accepted \\
\hline
\end{tabular}

As informed in Table 4, in general, subjective norms, attitude, self-efficacy, locus of control, entrepreneurship education and adversity quotient, have a score between 1.983 and 4.95. These results indicate that all variables were determined accepted. Based on calculations, the obtained value of $\mathrm{R}$-Square (R2) of 0.658 shows the influence of the independent variable is subjective norms, attitudes, self-efficacy, locus of control, entrepreneurial education, and adversity quotient of the dependent variable is the intention of entrepreneurship by $65.8 \%$, and $34.2 \%$, respectively 
influenced by other variables not included in the research model (see Table 5).

Table 5. Coefficient of Determination (R 2)

\begin{tabular}{lllll}
\hline Model & $\mathbf{R}$ & R Square & Adjusted R Square & Std. Error of the Estimate \\
\hline 1 & $.811 \mathrm{a}$ & .658 & .641 & 3.142 \\
\hline
\end{tabular}

\section{DISCUSSIONS}

The set of questions aimed to understand the factors affecting students' entrepreneurial intention. The finding of this study confirmed that subjective norms can influence students' entrepreneurial intentions. Subjective norms relate to individual perceptions that are considered important for others that influence a person's mindset to do or not perform certain behaviors and their motivation to fulfill those desires (Weeden, 2013). In this study, subjective norms are measured by indicators of the closest person's opinion, the suggestion of the closest person, and the expectations of the closest person such as parents, friends, and family. The indicator of expectations from the closest person contributes the highest value of 0.4073 , followed by the closest person's opinion and the indicator of the closest person suggestion of 0.2964. Students tend to see from the point of view of the expectations of their closest people, for example, their parents propose to become entrepreneurs. This study supports previous research conducted by Putra et al. (2015) which suggested that subjective norms can influence entrepreneurial intentions. Indeed, the result of this study is in line with previous findings by Yousaf et al. (2015) which noted that subjective norms have an important role in developing students' intentions to become entrepreneurs

In addition to subjective norms, this study noted that attitude can drive students' entrepreneurial intentions. The indicator of the individual's attitude gives the highest value of 0.361 , followed by the behavior indicator taken by the individual of 0.3207 , and the indicator of the individual's emotional level of 0.3142 . These results indicate that students prefer a strong belief to become entrepreneurs, and students are eager to start entrepreneurship. Students will behave positively when they hear positive comments so that students become entrepreneurs because of their ideals, and students behave in a way that confuses their desires to be entrepreneurial. This finding confirmed a prior study by Putra et al. (2015), which explained that student intentions will be positive if the student's attitude is positive. This tendency will significantly determine students to start a business or become entrepreneurs. Similarly, this study supports Linan and Chen. (2009); Ferla et al. (2009); Powell (2013); Yohana et al. (2020), which showed that entrepreneurial attitudes affect students' entrepreneurial intentions.

In the self-efficacy variable, the indicator for individual behavior in completing the task provides the highest value of 0.3588 , followed by the indicator for the level of a person's ability to complete the task of 0.3444 and the indicator for the level of difficulty of the task that can be handled by individuals approximately to 0.2968. Students' complete assignments in a relaxed manner and complete tasks in a hurry if the assignment is nearing the deadline. Furthermore, students can complete assignments carefully and correctly, complete any assignments quickly and accurately. This study in accordance with Hidayah and Atmoko (2014), which explained self-efficacy is an individual's belief in his or her ability to organize and display effective performance to complete certain tasks well. This finding also confirmed a preliminary study by Kurczewska and Białek (2014), which prove that the level of self-efficacy affects entrepreneurial intention. When selfefficacy is insufficient, a person becomes less enthusiastic about acting, so that the intention to do entrepreneurship becomes low and vice versa. This research is strengthened some previous works by Handaru (2015); Zurriaga (2016), which confirmed this correlation.

This fourth hypothesis pointed out that locus of control contributes to students' entrepreneurial intentions. In detail, individual fate is another indicator that provides the highest value to the locus of control variable of 0.3491 , followed by individual responsibility for a situation analysis of 0.3448 and individual luck indicator of 0.3061 . These results remark that the fate of students has an important effect on student success put a robust individual in the locus of control, so if luck is good, then success will be obtained individual responsibility situation analysis, namely 
students analyze the impact of decisions that students make and students work hard on success in entrepreneurship. This will increase the student's locus of control and individual luck, namely whether students succeed or not in entrepreneurship, depending on luck in the future, meaning this luck makes the intention trying high. This research reinforces previous studies by Powell (2013); Adnyana and Purnami (2016), which demonstrated that locus of control greatly influences students' intention to start a business.

Furthermore, entrepreneurship education plays a crucial role in determining students' entrepreneurial intentions. Precisely, the indicators of guidance, with sub-indicators of the cognitive value of learning, gave the highest value contribution to the entrepreneurship education variable of 0.3436 , followed by the learning attitude indicator of 0.3159 , and teaching indicator was 0.3159 . These results indicate that entrepreneurship education is the strongest indicator of the cognitive value of learning, namely the value of entrepreneurship courses is always good and the value of entrepreneurship courses convincing students to open a business. Entrepreneurship teaching indicators, namely lecturers teaching entrepreneurship courses well and students' knowledge in entrepreneurship, are supported by teaching lecturers in class attractively. Indicators of learning attitudes, namely students' understanding of entrepreneurship courses, make sure to start entrepreneurship, and student attitudes during entrepreneurship learning are good. This finding confirmed some major studies by Carda (2016); Saptono et al. (2020), which mentioned that entrepreneurship education significantly influences students' entrepreneurial intentions. Indeed, Karimi et al. (2016) emphasized that entrepreneurship education shapes students' mindsets, attitudes, and behavior to become great entrepreneurs, which leads them to choose entrepreneurship as a career choice.

The last finding of this study showed that the adversity quotient can promote students' entrepreneurial intentions. In the adversity quotient variable, the indicator that provided the highest contribution was the ability to bear the risk of 0.5139 , followed by the opportunity-oriented indicator of 0.4861 . The results of this study indicate that students dare to bear risks in the future. Regarding entrepreneurial intentions, the adversity quotient, according to Setiawan and Sukanti (2016) mentioning that an individual who has a high adversity quotient is thought to find it easier to undergo the profession as an entrepreneur because he can turn obstacles into opportunities. This research reinforces some preliminary studies by Handaru (2015); Yohana et al. (2016), which stated that the level of adversity quotient can affect students' entrepreneurial intentions. It will be able to move existing obstacles or challenges into an opportunity with various creativity and abilities individual.

\section{CONCLUSIONS AND SUGGESTION}

This study concluded that students' entrepreneurial intentions can be explained by students' subjective norms, entrepreneurial attitudes, self-efficacy, locus of control, and adversity quotient. This study also found a crucial role of entrepreneurship education in driving the intention of being entrepreneurs. The finding implicates that students have the advantage of factors such as encouragement from those closest to them, a supportive attitude to start a business, steady selfefficacy, good self-control, supported by their good knowledge of entrepreneurship, and their own thinking patterns well-structured will be more possible for him or her to start entrepreneurship. On the other hand, students who do not have the factors previously mentioned do not allow to start entrepreneurship. Therefore, increasing the supporting factors will increase the percentage to start entrepreneurship.

Further scholars are suggested to consider several matters. First, for students who want to become entrepreneurs, this is important because the initiative of the closest person can increase their desire to become entrepreneurial. Second, it needs to seek inspiration and learn from successful entrepreneurs to motivate students and eliminate doubts entrepreneurship. Lastly, supporting the campus is presented in providing more knowledge in entrepreneurship that is more practical instead of theoretical. 


\section{REFERENCES}

Adnyana, I. G. L. A., \& Purnami, N. M. (2016). Pengaruh pendidikan kewirausahaan, self-efficacy dan locus of control pada niat berwirausaha. E-Jurnal Manajemen, 5(2), 1160-1188.

Ajzen, I. (2005). Attitudes, personality, and behavior. McGraw-Hill Education (UK).

Asante, E. A., \& Affum-Osei, E. (2019). Entrepreneurship as a career choice: The impact of locus of control on aspiring entrepreneurs' opportunity recognition. Journal of Business Research, 98, 227-235.

Badri, R., \& Hachicha, N. (2019). Entrepreneurship education and its impact on students' intention to start up: A sample case study of students from two Tunisian universities. The International Journal of Management Education, 17(2), 182-190.

Bosma, N., Sanders, M., \& Stam, E. (2018). Institutions, entrepreneurship, and economic growth in Europe. Small Business Economics, 51(2), 483-499.

BPS. (2019). Pengangguran terbuka menurut pendidikan tertinggi yang ditamatkan 1986 - 2019. Retrieved from bps.go.id

Carda, A. Z., \& Kageyama, K. (2016). Entrepreneurial distance: A novel evaluation tool of entrepreneurial intention. Journal of Economics and International Finance, 8(9), 142-147.

Cui, J., Sun, J., \& Bell, R. (2019). The impact of entrepreneurship education on the entrepreneurial mindset of college students in China: The mediating role of inspiration and the role of educational attributes. The International Journal of Management Education, 100296.

Fenech, R., Baguant, P., \& Ivanov, D. (2019). Entrepreneurial attitudes, self-efficacy, and subjective norms amongst female Emirati entrepreneurs. International Journal of Entrepreneurship, 23(1), 1-11.

Ferla, J., Valcke, M., \& Cai, Y. (2009). Academic self-efficacy and academic self-concept: Reconsidering structural relationships. Learning and individual differences, 19(4), 499-505.

Ferreira, J. J., Fayolle, A., Fernandes, C., \& Raposo, M. (2017). Effects of Schumpeterian and Kirznerian entrepreneurship on economic growth: panel data evidence. Entrepreneurship \& Regional Development, 29(1-2), 27-50.

Fethi, A., \& Mohammed, B. S. (2019). Explaining online purchase intention: Validating technology acceptance model via structural equation model. Microeconomics and Macroeconomics, 7(1), 17.

Hair, J. F., Black, W. C., Babin, B. J., Anderson, R. E., \& Tatham, R. L. (2006). Multivariate data analysis. New Jersey: Prentice Hall

Handaru, A. W., Parimita, W., \& Mufdhalifah, I. W. (2015). Membangun intensi berwirausaha melalui adversity quotient, self-efficacy, dan need for achievement. Jurnal Manajemen dan Kewirausahaan, 17(2), 165-176.

Hidayah, N., \& Atmoko, A. (2014). Landasan sosial budaya dan psikologis pendidikan. Penerbit Gunung Samudera [Grup Penerbit PT Book Mart Indonesia].

Hsu, D. K., Burmeister-Lamp, K., Simmons, S. A., Foo, M. D., Hong, M. C., \& Pipes, J. D. (2019). "I know I can, but I don't fit”: Perceived fit, self-efficacy, and entrepreneurial intention. Journal of Business Venturing, 34(2), 311-326.

Karimi, S., Biemans, H. J., Lans, T., Chizari, M., \& Mulder, M. (2016). The impact of entrepreneurship education: A study of Iranian students' entrepreneurial intentions and opportunity identification. Journal of Small Business Management, 54(1), 187-209.

Karyaningsih, R. P. D., \& Wibowo, A. (2017). Hubungan kreativitas, efikasi diri dan intensi 
berwirausaha pada mahasiswa. Jurnal Pendidikan Ekonomi dan Bisnis (JPEB), 5(2), 162175.

Kuratko, D. F. (2005). The emergence of entrepreneurship education: Development, trends, and challenges. Entrepreneurship Theory and Practice, 29(5), 577-597.

Kurczewska, A., \& Bialek, J. (2014). Is the interplay between self-efficacy and entrepreneurial intention gender-dependent. Argumenta Oeconomica, 2(33), 23-38.

Lin, S., Winkler, C., Wang, S., \& Chen, H. (2020). Regional determinants of poverty alleviation through entrepreneurship in China. Entrepreneurship \& Regional Development, 32(1-2), 4162.

Liñán, F., \& Chen, Y. W. (2009). Development and cross-cultural application of a specific instrument to measure entrepreneurial intentions. Entrepreneurship Theory and Practice, 33(3), 593-617.

Mat, S. C., Maat, S. M., \& Mohd, N. (2015). Identifying factors that affecting the entrepreneurial intention among engineering technology students. Procedia-Social and Behavioral Sciences, 211, 1016-1022

Oluyemi, O. T., Ajayi, A. K., Abiola, A. O., \& Ajibade, Q. T. (2018). Entrepreneurship education and national development in Nigeria. International Journal of Innovative Education Research, 6(3), 34-39.

Papagiannis, G. D. (2018). Entrepreneurship education programs: The contribution of courses, seminars and competitions to entrepreneurial activity decision and to entrepreneurial spirit and mindset of young people in Greece. Journal of Entrepreneurship Education, 21(1), 1-21.

Powell, B. C. (2013). Dilemmas in entrepreneurship pedagogy. Journal of Entrepreneurship Education, 16, 99-114.

Putra, A. R. A., Rahyuda, K., \& Yasa, N. N. K. (2015). Sikap berwirausaha memediasi locus of control dan norma subyektif dengan niat berwirausaha (Studi: Mahasiswa Program Diploma Fakultas Ekonomi dan Bisnis Universitas Udayana). E-Jurnal Manajemen, 4(12), 4501-4528.

Şahin, F., Karadağ, H., \& Tuncer, B. (2019). Big five personality traits, entrepreneurial self-efficacy and entrepreneurial intention: A configurational approach. International Journal of Entrepreneurial Behavior \& Research, 25(6), 1188-1211

Santos, S. C., \& Liguori, E. W. (2019). Entrepreneurial self-efficacy and intentions: Outcome expectations as mediator and subjective norms as moderator. International Journal of Entrepreneurial Behavior \& Research, 26(3), 400-410

Saptono, A., Wibowo, A., Narmaditya, B. S., Karyaningsih, R. P. D., \& Yanto, H. (2020). Does entrepreneurial education matter for Indonesian students' entrepreneurial preparation: The mediating role of entrepreneurial mindset and knowledge. Cogent Education, 7(1), 1836728.

Setiawan, D., \& Sukanti, S. (2016). Pengaruh ekspektasi pendapatan, lingkungan keluarga dan pendidikan kewirausahaan terhadap minat berwirausaha. Jurnal Profita: Kajian Ilmu Akuntansi, 4(7), 1-12.

Shepherd, D. A., Parida, V., \& Wincent, J. (2020). Entrepreneurship and poverty alleviation: the importance of health and children's education for slum entrepreneurs. Entrepreneurship Theory and Practice, 1042258719900774.

Tognazzo, A., Gianecchini, M., \& Gubitta, P. (2017). Educational context and entrepreneurial intentions of university students: An Italian study. In Entrepreneurship Education. Emerald Publishing Limited.

Urbano, D., Aparicio, S., \& Audretsch, D. (2019). Twenty-five years of research on institutions, entrepreneurship, and economic growth: what has been learned?. Small Business Economics, 53(1), 21-49. 
Wardana, L. W., Narmaditya, B. S., Wibowo, A., Mahendra, A. M., Wibowo, N. A., Harwida, G., \& Rohman, A. N. (2020). The impact of entrepreneurship education and students' entrepreneurial mindset: the mediating role of attitude and self-efficacy. Heliyon, 6(9), e04922.

Wedayanti, N. P. A. A., \& Giantari, I. G. A. K. (2016). Peran pendidikan kewirausahaan dalam memediasi pengaruh norma subyektif terhadap niat berwirausaha. E-Jurnal Manajemen, 5(1), 533-560.

Weeden, C. (2013). Responsible and ethical tourist behaviour (Vol. 30). Routledge.

Yohana, C, Firdausi. R. R. D., \& Ishak. (2020). Analyzing the generation milenial intersitas entrepreneurship: Entrepreneurship attitude is and locus of influential control, International Journal of Innovations in Engineering Research and Technology, 7(6), 99-103.

Yohana. C., Pururita. D., \& Puspa, D. (2016). Development of entrepreneurial intentional in relation to adversity quotient and self-efficacy for students of economics of State University of Jakarta, The 1st International Conference on Economic Educational and Entrepreneurship 2016.

Yousaf, U., Shamim, A., Siddiqui, H., \& Raina, M. (2015). Studying the influence of entrepreneurial attributes, subjective norms and perceived desirability on entrepreneurial intentions. Journal of Entrepreneurship in Emerging Economies, 7(1), 23-34. 